\title{
Pengembangan Modul dan Pelatihan Keperawatan Spiritual dalam Upaya Peningkatan Pengetahuan dan Psikomotor Perawat
}

\author{
Murtiningsih $^{1}$, Lusianah$^{2}$, Nurainun ${ }^{3}$ \\ 1'2Program Studi Profesi Ners, STIKes Jayakarta \\ ${ }^{3}$ Kepala Ruangan ICCU RSUD Pasar Rebo Jakarta \\ Email: murtiningsihkadun@gmail.com
}

Submitted : 28/03/2020

Accepted: 04/04/2020

Published:16/06/2020

\begin{abstract}
Nursing care for patients needs to be given holistic care including biopsychososiospiritual. Based on situation analysis through Focus Group Discussion (FGD), it was found that the majority of ICCU room nurses at RSUD Pasar Rebo chose spiritual nursing training priorities (100\%). Community service activities are carried out by STIKes Jayakarta Lecturers and STIKes Jayakarta Nursing Student. The worship guide module for the sick has been compiled and has received a Copyright certificate. Spiritual Nursing Training using a module was conducted on December 24, 2019 for 17 nurses in the ICCU room. There were 7 participants who took the pre test and post test. The pretest knowledge of the category was poor $85.7 \%$, fair $14.3 \%$. The increase in knowledge occurred during the post-test, namely a good category of $71.4 \%$ and fair category of $28.6 \%$. Psychomotor assessment of the practice of worship of patients against 13 nurses obtained psychomotor pre-test poor $30.8 \%$, good $69.2 \%$ and good post-test $100 \%$.
\end{abstract}

Keywords: knowledge, psychomotor, spiritual nursing care

\begin{abstract}
Abstrak
Asuhan keperawatan pada pasien perlu diberikan secara holistik meliputi biopsikososiospiritual. Berdasarkan Analisa situasi melalui Focus Goup Discussion (FGD) didapatkan bahwa mayoritas perawat ruang ICCU RSUD Pasar Rebo memilih prioritas pelatihan keperawatan spiritual (100\%). Kegiatan pengabdian kepada masyarakat ini dilakukan oleh Dosen STIKes Jayakarta beserta Mahasiswa Program Studi Ners STIKes Jayakarta. Modul panduan ibadah bagi orang sakit telah tersusun dan telah mendapatkan sertifikat Hak Cipta. Pelatihan Keperawatan Spiritual dengan menggunakan modul telah dilakukan pada tanggal 24 Desember 2019 terhadap 17 orang perawat di ruang ICCU. Peserta yang mengikuti pre test dan post test sebanyak 7 orang. Pengetahuan pretest kategori kurang $85,7 \%$, cukup $14,3 \%$. Peningkatan pengetahuan terjadi saat post test yaitu kategori baik $71,4 \%$ dan kategori cukup 28,6\%. Penilaian psikomotor praktek ibadah pasien terhadap 13 perawat didapatkan pre test psikomotor Kurang 30,8\%, baik 69,2 \% dan post test baik $100 \%$.
\end{abstract}

Kata kunci: asuhan keperawatan spiritual, pengetahuan, psikomotor

\section{PENDAHULUAN}

Perawat dalam memberikan asuhan keperawatan diharapkan secara komprehensif bio, psiko, sosio, spiritual. Akan tetapi pada kenyataannya pemenuhan kebutuhan spriritual pasien belum dilakukan secara optimal. Berdasarkan penelitian (Murtiningsih \& Nedra, 2019 ) tentang praktek ibadah pasien didapatkan mayoritas pasien $(41.5 \%)$ selama dirawat di Rumah Sakit tidak pernah melakukan sholat. Alasan pasien tidak melakukan ibadah sholat ketika dirawat di Rumah sakit mayoritas (23.1\%) karena tidak tahu cara sholat, sebelum sakit jarang sholat (18.5\%), sebagian (9.2\%) berpendapat kalau sakit tidak perlu sholat, serta tidak ada perlengkapan sholat (4.6\%). Rekomendasi dari hasil penelitian tersebut 
yaitu diperlukannya pelatihan bagi perawat tentang praktek ibadah sholat dan rukhshah (kemudahan) melakukan ibadah bagi pasien yang dirawat di Rumah Sakit.

Intensive Coronary Care Unit (ICCU) adalah unit perawatan intensif untuk penyakit jantung, terutama penyakit jantung coroner, serangan jantung, gangguan irama jantung yang berat, gagal jantung. Asuhan keperawatan yang diberikan pada pasien yang dirawat di ruang ICCU mencakup biopsikososiospiritual yang komprehensif, namun pemenuhan kebutuhan spiritual kurang terpenuhi secara maksimal dirasakan oleh pasien, keluarga maupun petugas kesehatan.

Berdasarkan hasil wawancara dengan kepala ruangan, perawat pelaksana dan pasien didapatkan bahwa kurang memahami tentang pemenuhan kebutuhan spiritual dan praktek ibadah orang sakit, belum ada sarana dan petunjuk untuk membantu ibadah orang sakit. Pasien Pasien mengatakan setuju untuk dibantu melakukan ibadah tapi tidak mengetahui caranya. Berdasarkan hasil observasi pada saat jam sholat pasien tidak mendapatkan bimbingan untuk melakukan ibadah, tetapi hanya menganjurkan berzikir.

Seorang Perawat Muslim akan membantu pasien Muslim dalam memenuhi kebutuhan spiritual Muslim. Dalam memberikan asuhan keperawatan perawat berdasarkan paradigm keperawatan sebagai konsep sental disiplin ilmu keperawatan. Paradigma keperawatan tersebut meliputi Manusia, kesehatan, lingkungan dan keperawatan. (Kozier, 2008).

Paradigma Keperawatan Islam adalah cara pandang, keyakinan, nilai-nilai dan konsep-konsep dalam menyelenggarakan profesi keperawatan yang melaksanakan sepenuhnya prinsip dan ajaran Islam. (Achir Yani, 2015)
Keperawatan Islami adalah pelayanan keperawatan sebagai bentuk ibadah berdasarkan AlQur'an dan Hadis untuk mencari Ridho Allah SWT, dengan karakteristik professional ramah, amanah, istiqomah, sabra dan Ikhlas. (Sudalhar, 2011). Sebagai seorang perawat Muslim diharapkan dapat membantu pasien memenuhi kebutuhan spiritual. Salah satu pemenuhan kebutuhan spiritual adalah pasien dapat melakukan ibadah sholat lima waktu yang merupakan kewajiban seorang Muslim.

Dalam AlQur'an Surat Azzariyat (51) ayat 56 yang artinya "tidak Aku Cptakan jin dan manusia kecuali untuk beribadah". Seorang perawat Muslim ketika membantu pasien melakukan ibadahnya itu merupakan ibadah juga baginya jika dilakukan dengan ikhlas dan sesuai dengan syariat.

Dalam Al Qur'an Surat AnNisa (4) ayat 103 "Sesungguhnya sholat adalah satu ketetapan yang diwajibkan kepada orangorang yang beriman yang telah ditentukan waktunya". Sholat merupakan rukun Islam yang pertama kali diwajibkan, dan merupakan ibadah pertama yang akan dihisab ketika hari kiamat. Setiap Muslim wajib melaksanakan sholat lima waktu dalam sehari yaitu Subuh, Zuhur, Ashar, Magrib dan Isya. Kewajiban sholat tidak boleh ditinggalkan jika tidak mampu berdiri boleh duduk, berbaring atau dengan isyarat mata dan hati. Bagi pasien yang dirawat di Rumah sakit mempunyai hambatan dalam melaksanakan ibadah sholat tersebut, maka tugas perawat Muslim adalah membantu pasien untuk melakukan ibadah. (Jais Kamus, 2013)

Seorang perawat Muslim akan memberikan asuhan keperawatan Muslim dalam memenuhi kebutuhan spiritual Muslim. Perawat dapat membantu pasien dalam melakukan ibadah ketika di Rumah Sakit. Pasien yang dirawat di Rumah Sakit ada rukhshah dalam melakukan ibadah di 
Rumah Sakit. Definisi Rukhsah dari segi Bahasa adalah mempermudahkan. Definisi Rukhsah dari segi istilah adalah suatu hokum yang berlaku dalam keadaan yang bertentangan dengan dalil asli karena terdapat keuzuran. (Ahmad Marzuk, 2011).

\section{TARGET DAN LUARAN}

\section{Target}

Target dalam kegiatan pengabdian kepada masyarakat ini adalah:
a. Perawat Ruang ICCU RSUD Pasar Rebo
b. Pasien yang dirawat di Ruang ICCU

\section{Luaran}
a. Tersusunnya modul panduan ibadah orang sakit
b. Pengetahuan Perawat tentang pemenuhan kebutuhan spiritual
c. Ketrampilan perawat dalam membantu ibadah pasien
d. Implementasi pemenuhan kebutuhan spiritual pasien

\section{METODE PELAKSANAAN}

1. Waktu dan Tempat Kegiatan

Kegiatan Pelatihan keperawatan spiritual dilaksanakan pada 24 Desember 2019 di Ruang perawat ICCU RSUD Pasar Rebo. Selanjutnya dilakukan aplikasi langsung kepada pasien yang dirawat di ruang ICCU RSUD Pasar Rebo.

2. Tujuan
a. Peserta dapat memahami pemenuhan kebutuhan spiritual pasien.
b. Peserta dapat mendemonstrasikan praktek ibadah pasien.
c. Terlaksananya bimbingan ibadah pasien.

3. Sasaran

Sasaran dalam kegiatan ini adalah perawat ruang ICCU RSUD Pasar Rebo sebanyak 17 orang.

4. Kontribusi peserta a. Menjadi peserta kegiatan pengabdian kepada masyarakat

b. Mempraktekkan bantuan ibadah pasien

5. Pelaksanaan kegiatan Pengabdian Kepada Masyarakat

Kegiatan Awal

a. Menyusun proposal kegiatan pengabdian kepada masyarakat

b. Membuat modul panduan ibadah bagi orang sakit

c. Menyiapkan peralatan untuk bimbingan ibadah pasien

\section{Pelaksanaan Kegiatan}

Kegiatan pengabdian kepada masyarakat ini dilaksanakan selama 2 minggu dimulai dengan tahapan sebagai berikut:

a. Persiapan,

Persiapan kegiatan pengabdian masyarakatini adalah sebagai berikut:

1) Melakukan Focus Group Discussion (FGD) untuk Analisa situasi pelatihan yang diperlukan

2) Menyepakati pelatihan keperawatan spiritual.

3) Menyusun modul panduan ibadah orang sakit.

4) Mencetak modul sejumlah peserta.

5) Membagi tugas pendaftaran, konsumsi, perlengkapan dan dokumentasi.

6) Menata ruangan yang akan digunakan untuk pelaksanaan pengabdian kepada masyarakat.

b. Pelaksanaan

1) Ceramah dan Diskusi

Pelatihan diawali dengan kegiatan ceramah dan diskusi. Narasumber: Murtiningsih, SKp, M.Kep, Sp. Mat. Pelatihan dilaksanakan pada tanggal 24 Desember 2019 di ruang perawat ICCU RSUD Pasar Rebo.

2) Demonstrasi

Kegiatan ini merupakan lanjutan dari ceramah dan diskusi dengan 
mendemonstrasikan cara bersuci, wudhu, tayamum dan ibadah orang sakit.

3) Tim Pengabdian masyarakat membagikan modul sederhana terkait panduan ibadah orang sakit

4) Perawat dibagi menjadi 8 kelompok, masing-masing kelompok dibimbing oleh coach.

5) Setiap kelompok dipimpin oleh seorang coach dari tim pengabdian kepada masyarakat yang membimbing pada saat mengaplikasikan keperawatan spiritual pada pasien.

6) Aplikasi keperawatan spiritual pada pasien yang dirawat di ruang ICCU RSUD Pasar Rebo

7) Pihak yang terlibat dalam kegiatan pengabdian masyarakat ini Murtiningsih, M.Kep, Sp. Mat dan Lusianah, SKp, M.Kep dosen STIKes Jakarta, Hendra Maulana, S.Kep Diklat RSUD Pasar Rebo, Ns Nurainun, S.Kep Kepala Ruangan ICCU RSUD Pasar Rebo Jakarta. Panitia mahasiswa yang terlibat yaitu, Anderson, S.Kep, Christiana A.E, S.Kep, Dwi Astuti, S.Kep, Dwi Susilowati, S. Kep, Ika Rostika, S.Kep, Natarina Ariani, S.Kep, Ririn Tri Wahyuni, S. Kep,Yani Megawati, S.Kep

c. Evaluasi kegiatan.

1) Rencana kegiatan pengabdian masyarakat pada kesempatan ini dilakukan di luar kampus STIKes Jayakarta

2) Pendanaan dari STIKes Jayakarta.

3) Peserta yang mengikuti pelatihan 17 orang.

4) Pada saat pelaksanakan perawat yang mengikuti pre dan post test sebanyak 7 orang
5) Perawat yang mengikuti demonstrasi praktek ibadah pasien sebanyak 13 orang.

6) Perawat tidak dapat sepenuhnya mengikuti pelatihan dari awal sampai akhir karena pada shift pagi perawat tetap melakukan asuhan keperawatan pada pasien.

7) Pengetahuan pretest kategori kurang $85,7 \%$, cukup $14,3 \%$. Peningkatan pengetahuan terjadi saat post test yaitu kategori baik $71,4 \%$ dan kategori cukup 28,6\%.

8) Penilaian psikomotor praktek ibadah pasien terhadap 13 perawat didapatkan pre test psikomotor Kurang 30,8\%, baik 69,2 \% dan post test baik $100 \%$.

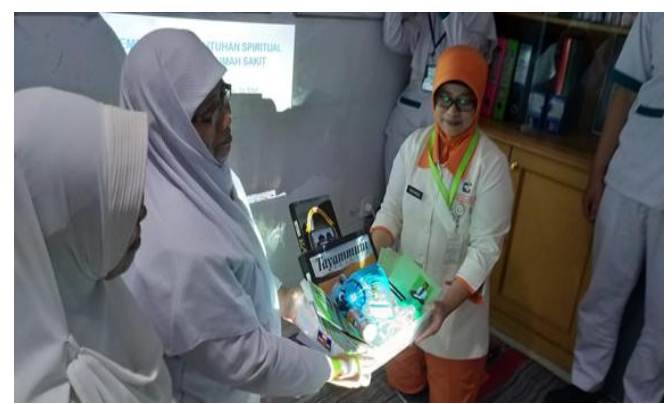

Gambar 1. Serah terima modul pelatihan dan perlengkapan ibadah.

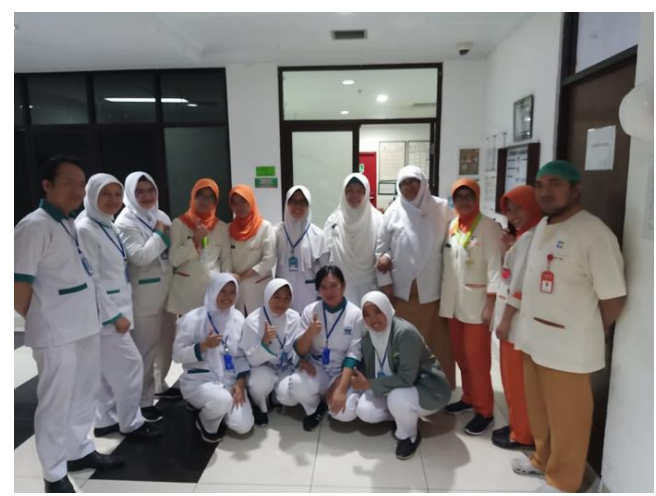

Gambar 2. Panitia dan peserta Pelatihan

Keperawatan spiritual 


\section{HASIL DAN PEMBAHASAN}

Metode yang digunakan dalam kegiatan ini adalah metode ceramah dan demonstrasi. Sebelum dan setelah pelatihan keperawatan spiritual dilakukan pre test dan post post test pengetahuan dan psikomotor peserta.

Berdasarkan hasil pre test pengetahuan didapatkan hasil peserta dengan kategori pengetahuan kurang $85,7 \%$, cukup $14,3 \%$. Setelah diberikan pelatihan terjadi peningkatan pengetahuan pada post test yaitu pengetahuan dengan kategori baik 71,4\% dan kategori cukup 28,6\%.

Hasil penelitian terkait pengetahuan perawatan spiritual juga telah dilakukan terhadap perawat di Rumah Sakit Dustira dengan jumlah responden 70 orang didapatkan bahwa hampir setengah responden $(42,9 \%)$ berpengetahuan baik, hampir setengah responden $(41,4 \%)$ berpengetahuan cukup, dan sebagian kecil responden $(15,7 \%)$ berpengetahuan kurang.(Kiran \& Dewi, 2017). Dari hasil penelitian tersebut menunjukkan pengetahuan perawat tentang perawatan spiritual masih perlu ditingkatkan.

Salah satu upaya yang dilakukan untuk meningkatkan pengetahuan perawat tentang perawatan spiritual yaitu melalui kegiatan pelatihan tentang keperawatan spiritual. Pengetahuan dan ketrampilan perawat tentang asuhan keperawatan spiritual perlu diberikan untuk membantu pasien yang dirawat di rumah sakit dapat melakukan ibadah di rumah sakit.

Selain tingkat pengetahuan, penilaian psikomotor juga dilakukan tentang praktek ibadah pasien terhadap 13 perawat. Hasil pretest dan post test didapatkan pre test psikomotor Kurang 30,8\%, baik 69,2\% dan post test seluruh peserta dapat mendemonstrasikan ulang cara membantu pasien dalam bersuci, wudhu dan tayamum serta praktek ibadah sholat pasien. Penilaian psikomotor setelah pelatihan didapatkan seluruh peserta mendapatkan nilai dengan kategori baik yaitu 100\%. Pasien yang dirawat dirumah sakit memiliki keterbatasan dalam melakukan ibadah ketika sakit. Berdasarkan hasil penelitian tentang praktek ibadah sholat pasien di Rumah Sakit didapatkan bahwa sebagian besar (77.7\%, $\mathrm{n}=129$ ) pasien tidak melakukan sholat ketika dirawat. Alasan pasien tidak melakukan sholat diantaranya karena tidak ada yang membimbing sholat $(48.2 \%, \mathrm{n}=80)$, tidak ada yang membantu untuk wudhu atau tayamum (47.6\% , n=79).(Aris, Jaafar, \& Umar, 2017).

Berdasarkan hasil penelitian tersebut direkomendasikan untuk meningkatkan pengetahuan dan ketrampilan perawat untuk memberikan edukasi kepada pasien dalam membantu ibadah pasien di rumah sakit sangat dibutuhkan oleh pasien.

Pasien yang dirawat di ruang ICCU tidak dapat setiap saat ditemani oleh keluarganya, sehingga peran perawat diperlukan dalam membantu praktek ibadah pasien yang dirawat. Sebelum membantu pasien untuk melakukan ibadahnya maka diperlukan pengetahuan dan ketrampilan perawat. Sehingga diharapkan melalui kegiatan pengabdian masyarakat ini perawat dapat meningkatkan pengetahuan dan ketrampilan membantu ibadah pasien untuk memenuhi kebutuhan spiritual pasien.

Pengetahuan dan ketrampilan perawat dalam membantu pasien melakukan ibadah merupakan salah satu tugas perawat untuk memenuhi kebutuhan spiritual pasien. Hal tersebut sesuai dengan undang-undang nomor 44 tahun 2009 pasal 32 tentang perlindungan hak pasien bahwa pasien mempunyai hak menjalankan ibadah sesuai agama atau kepercayaan yang dianutnya selama hal itu tidak mengganggu pasien lainnya; (Kemenkes, 2009). 


\section{KESIMPULAN DAN SARAN 1. Kesimpulan}

Evaluasi pelatihan didapatkan pengetahuan pretest kategori kurang 85,7\%, cukup $14,3 \%$. Peningkatan pengetahuan terjadi saat post test yaitu kategori baik 71,4 $\%$ dan kategori cukup 28,6\%. Penilaian psikomotor praktek ibadah pasien terhadap 13 perawat didapatkan pre test psikomotor Kurang 30,8\%, baik 69,2\% dan post test baik $100 \%$.

\section{Saran}

a. Perlu dilakukannya follow up terus menerus terhadap peserta pelatihan dan magang untuk meningkatkan ketrampilan.

b. Dilakukan survey terhadap kepuasan pasien terhadap aplikasi asuhan keperawatan yang holistic.

\section{UCAPAN TERIMAKASIH}

Tim Pengabdian Kepada Masyarakat mengucapkan terimakasih kepada:

1. STIKes Jayakarta yang telah membantu dana dan administrasi sehingga terlaksananya kegiatan Pengabdian Kepada Masayarakat.

2. Bidang Diklat RSUD Pasar Rebo.

3. Kepala ruangan dan perawat ruang ICCU RSUD Pasar Rebo.

4. Mahasiswa Ners praktek stase manajemen keperawatan

5. Pasien yang dirawat di ruang ICCU beserta keluarga.

\section{DAFTAR PUSTAKA}

Achir Yani. (2015). Paradigma Keperawatan Dalam Perspektif Islam. Disampaikan pada seminar dan Workshop keperawatan Islami STIKes Jayakarta.

Ahmad Marzuk Shaary. (2011). Panduan Pengurusan Ibadah Pesakit. Disampaiakan pada seminar Kejururawatan Muslim Kolej Universiti
Islam Antarabangsa Selangor.

Arham Ahmad Yasin. AlQur'an terjemahan:

Mushaf Ash-Shahib. Jakarta: Hilal Media.

Aris, S., Jaafar, H., \& Umar, N. S. (2017). Knowledge , Attitude And Practice Of Performing Prayers ( Salat) Among Muslim Patients In Hospital Langkawi, Kedah: Roles Of Muslim Healthcare. (May). https://doi.org/10.1166/asl.2017.8975

Aris Munandar (2013). Kemudahan. E book www.ibnumajjah.com

Harmy Mohd Yusuf, et all. (2012). Fikah Perubatan. Kuala Lumpur: PTS Millenia Sdn. Bhd.

Jais Kamus. (2013). Ibadah Pesakit. Disampaikan pada Training of Trainer Fasilitator Mesra Ibadah Jabatan Agama Islam Selangor, Malaysia.

Kemenkes. (2009). Undang-undang No 44 Tahun 2009 tentang Rumah Sakit. Retrieved from kesmas. kemenkes.go.id/perpu website: kemenkes.go.id

Kiran, Y., \& Dewi, U. S. P. (2017). Pengetahuan dan Sikap Perawat dalam Memenuhi Kebutuhan Psikologis dan Spiritual Klien Terminal. Jurnal Pendidikan Keperawatan Indonesia, $3(2)$, 182. https://doi.org/10.17509/jpki.v3i2.9425

Kozier, at all. (2008). Fundamental of Nursing. New Jersey: Pearson.

Murtiningsih \& Nedra. (2019). Praktek ibadah sholat pasien di Rumah Sakit X. Jakarta: STIKes Jayakarta.

Sudalhar. (2011). Keperawatan Islami. Jawa Timur: CV. Duta Ilmu Indonesia.

Tata cara Sholat Orang sakit. https://muslim.or.id/37763-tata-carashalat-orang-yang-sakit.html

Terjemahan AlQur'an. https://tafsirweb.com 